\title{
DAYA INFEKSI DAN EFEKTIVITAS FUNGI MIKORIZA ARBUSKULAR Gigaspora margarita PADA TANAMAN JAGUNG DENGAN MASA SIMPAN YANG BERBEDA
}

\section{INFECTIVITY AND EFFECTIVENESS OF ARBUSCULAR MYCORRHIZA FUNGI Gigaspora margarita OF DIFFERENT STORAGE TIME ON MAIZE}

\author{
Maria Viva Rini ${ }^{1 *}$, Lita Andriyyani², M.A. Syamsul Arif ${ }^{3}$ \\ ${ }^{1}$ Jurusan Agronomi dan Hortikultura Fakultas Pertanian Universitas Lampung \\ ${ }^{2}$ Jurusan Agroteknologi Fakultas Pertanian Universitas Lampung \\ ${ }^{3}$ Jurusan Ilmu Tanah Fakultas Pertanian Universitas Lampung \\ *E-mail:maria.vivarini@fp.unila.ac.id
}

\begin{abstract}
Arbuscular Mycorrhizal Fungi (AMF) is a type of mycorrhizal fungi which forms the most widespread mutualistic symbiotic with plant roots. Nowadays, biofertilizer containing spores of AMF has been developed, however reports on how long this fertilizer can be stored without losing its infectivity and effectiveness are still few. Therefore, this study aimed to evaluate (1) the effect of length of storage period on infectivity of spores of Gigaspora margarita, and (2) the effect of length of storage period on plant growth of maize. G. margarita spores which had been stored for 0, 6, and 22 months were inoculated onto roots of germinated seed of maize and planted in $450 \mathrm{ml}$ pot containing a mixture of sterilized sand and zeolite (2:1 by volume). Root infection was examined at 1, 2, 3 weeks after AMF inoculation. For effectiveness study, the germinated seeds of maize were inoculated with G. margarita spores and planted in polybag containing $8 \mathrm{~kg}$ of mixture of sterilized sand and zeolite and kept in greenhouse for 8 weeks. The results obtained showed that length of storage period affects the infectivity of G. margarita spore. G. margarita spores from all storage periods gave root infection more than $50 \%$ after 8 weeks of inoculation and hence improved the maize growth.
\end{abstract}

Keywords: Gigaspora margarita, effectivity, infectivity, storage time.

\begin{abstract}
ABSTRAK
Fungi mikoriza arbuskular (FMA) merupakan salah satu tipe mikoriza yang sangat luas penyebarannya dan membentuk simbiosis mutualisme dengan akar tanaman. Saat ini, pupuk hayati berbahan dasar spora mikoriza sudah banyak dikembangkan, namun laporan tentang berapa lama pupuk ini dapat disimpan tanpa spora kehilangan daya infeksi dan efektivitasnya sangat sedikit. Oleh karena itu, penelitian ini dilakukan dengan tujuan untuk mengevaluasi pengaruh masa simpan terhadap (1) daya infeksi spora Gigaspora margarita dan(2) pertumbuhan tanaman jagung. Spora G. margarita yang telah disimpan selama 0, 6, dan 22 bulan diinokulasikan ke akar kecambah jagung dan ditanam dalam pot bervolume $450 \mathrm{ml}$ berisi media tanam campuran pasir steril dan zeolite (2:1 berdasarkan volume). Infeksi akar diamati pada 1, 2, dan 3 minggu setelah inokulasi FMA. Untuk studi
\end{abstract}


efektivitas, kecambah jagung diinokulasi dengan spora G. margarita dan ditanam dalam polibag yang berisi $8 \mathrm{~kg}$ media dan dipelihara di rumah kaca selama 8 minggu. Hasil penelitian menunjukkan bahwa waktu simpan mempengaruhi daya infeksi FMA G. margarita. Spora G. margarita pada semua masa simpan berhasil menginfeksi akar lebih dari 50\% 8 minggu setelah inokulasi dan mampu meningkatkan pertumbuhan tanaman jagung.

Kata kunci: Gigaspora margarita, daya infeksi, efektivitas, masa simpan.

\section{PENDAHULUAN}

Fungi mikoriza arbuskula(FMA) termasuk ke dalam filum Glomeromycota merupakan mikroba tanah yang luas penyebarannya dan membentuk hubungan simbiosis dengan akar tanaman (Smith dan Read, 2008). Simbiosis ini bersifat mutualisme, yaitu fungi mikoriza membantu tanaman dalam menyerap unsur hara dan air dari dalam tanah dan sebaliknya fungi menerima senyawa karbon hasil fotosintesis dari tanaman inangnya (Strullu-Derrien et al., 2018). Meningkatnya serapan unsur hara dan air oleh tanaman yang bermikoriza menghasilkan pertumbuhan tanaman yang lebih baik dibandingkan tanaman kontrol tanpa mikoriza seperti yang dilaporkan pada tanaman gaharu oleh Rini et al., (2020) dan kelapa sawit oleh Krisnarini et al. (2018). Selain peningkatan penyerapan unsur hara dan air, FMA juga telah dilaporkan dapat meningkatkan laju fotosintesis tanaman inangnya, memperbaiki resistensi stomata, meningkatkan ketahanan tanaman serangan patogen tanah (Rini et al., 2000; Bharadwaj et al., 2008).

Dengan banyak manfaat yang dapat diperoleh tanaman jika bersimbiosis dengan fungi mikoriza, dewasa ini telah banyak dikembangkan pupuk hayati berbasis fungi ini. Pupuk hayati ini mulai menjadi perhatian karena bersifat ramah lingkungan, tidak menimbulkan efek residu, dapat mengurangi penggunaan pupuk kimia, dan hanya perlu sekali aplikasi dalam satu siklus hidup tanaman karena fungi bersifat obligat, hidup dalam akar tanaman.

Menurut Simanungkalit et al. (2006), pupuk hayati yang berkualitas harus memenuhi standar tertentu seperti jumlah dan efektivitas mikroba yang terdapat dalam pupuk, bahan pembawa, dan berapa lama masa simpan pupuk tersebut. Pupuk hayati yang baik mengandung mikroba dengan populasi tertentu yang dapat memberikan pengaruh yang positif bagi pertumbuhan dan produksi tanaman. Masa simpan pupuk juga sangat berperan penting karena akan mempengaruhi efektivitas dari mikroba yang terdapat di dalam pupuk. Seberapa lama pupuk tersebut dapat disimpan tanpa mengurangi efektivitas mikroba yang terdapat di dalam pupuk perlu dikaji secara mendalam.

Struktur pembentuk fungi mikoriza arbuskular berupa spora, hifa, vesikel, dan arbuskula. Struktur ini dapat digunakan sebagai sumber inokulum (propagul) untuk menginfeksi akar tanaman (Smith dan Read, 2008). Pada umumnya, pupuk hayati mikoriza yang beredar saat ini mengandung spora sebagai sumber inokulum. Menurut Brundrett et al. (2008), spora FMA mampu bertahan di dalam tanah hingga 6 bulan tanpa tanaman inangnya, bahkan ada yang dapat 
bertahan sampai dua tahun. Namun, apakah sporaspora tersebut masih memiliki kemampuan untuk menginfeksi tanaman dengan baik tidak dijelaskan. Oleh karena itu, penelitian ini dilaksanakan untuk mengetahui (1) apakah daya infeksi spora Gigaspora margarita dipengaruhi oleh lamanya waktu penyimpanan dan (2) berapa lamakah waktu penyimpanan yang masih menghasilkan infeksi akar $>50 \%$ dan masih mampu meningkatkan pertumbuhan tanaman jagung.

\section{BAHAN DAN METODE}

Waktu dan tempat. Penelitian dilaksanakan dari bulan Februari - Juni 2015 dan dilakukan di Laboratorium Produksi Perkebunan dan Rumah Kaca, Fakultas Pertanian, Universitas Lampung.

Alat dan bahan. Alat-alat yang digunakan dalam penelitian ini adalah mikroskop stereo dan majemuk, water bath, autoklaf, oven, saringan mikro (ukuran $500 \mu \mathrm{m}, 350 \mu \mathrm{m}$, dan $45 \mu \mathrm{m}$ ), cawan petri, pinset spora, timbangan elektrik, gelas preparat, polibag, dan alat tulis. Bahan yang digunakan adalah benih jagung, FMA Gigaspora margarita isolat MV 17 (koleksi Laboratorium Produksi Perkebunan Fakultas Pertanian Unila) yang disimpan dalam ruangan ber AC suhu $20 \pm 2{ }^{\circ} \mathrm{C}$, larutan $\mathrm{KOH} 10 \%, \mathrm{HCl} 1 \%$, Trypan Blue, Glycerol, pasir, zeolite, dan akuades.

Rancangan percobaan. Penelitian untuk melihat daya infeksi spora G. margarita dilaksanakan dengan menggunakan rancangan perlakuan tunggal tidak terstruktur yang terdiri dari 3 perlakuan lamanya waktu simpan inokulum yaitu: waktu simpan 0 bulan $\left(\mathrm{w}_{1}\right)$, waktu simpan 6 bulan $\left(\mathrm{w}_{2}\right)$ dan waktu simpan 22 bulan $\left(\mathrm{w}_{3}\right)$. Setiap perlakuan diulang sebanyak 3 kali. Perlakuan diterapkan ke dalam satuan percobaan menurut Rancangan Acak Kelompok (RAK). Untuk melihat perkembangan infeksi mikoriza pada akar tanaman, 3 tanaman secara destruktif disampling pada minggu ke 1, 2, dan 3. Oleh karena itu, setiap satuan percobaan diwakili oleh 9 tanaman.

\section{Tahapan penelitian uji daya infeksi}

Penyiapan media tanam, benih jagung, dan aplikasi FMA. Media tanam yang digunakan adalah campuran pasir sungai steril dan zeolite dengan perbandingan 2:1 (berdasarkan volume) dimasukkan ke dalam pot ukuran $450 \mathrm{ml}$. Benih jagung dikecambahkan terlebih dahulu dengan meletakkan benih yang sudah dicuci bersih di atas kertas merang yang telah dilembabkan selama 3 hari. Benih yang telah berkecambah kemudian ditanam dalam pot yang sudah berisi media tanam. Pada saat menanam, inokulum FMA G. margarita (mengandung \pm 300 spora) untuk setiap perlakuan diaplikasikan ke dalam lubang tanam. Pot yang sudah ditanami selanjutnya dipelihara di rumah kaca. Penyiraman dilakukan pada pagi hari dengan memberikan air sebanyak $50 \mathrm{ml} /$ pot. Pupuk urea dengan konsentrasi $2 \mathrm{~g} /$ liter diberikan sebanyak $10 \mathrm{ml} /$ pot pada 7 dan 14 hari setelah tanam.

Pengambilan data. Pengamatan infeksi FMA pada akar tanaman jagung dilakukan pada 1, 2, dan 3 minggu setelah tanam secara destruktif. Sebanyak 3 tanaman untuk setiap perlakuan dibongkar dan diambil akarnya secara acak sebanyak $\pm 2 \mathrm{~g}$. Akar tersebut 
kemudian diwarnai dengan trypan blue menurut metode Brundrett (2008). Akar yang sudah diwarnai selanjutnya disusun di atas gelas preparat dan persen infeksi akar diamati di bawah mikroskop majemuk dengan pembesaran 100x.

\section{Tahapan penelitian uji efektivitas}

Rancangan percobaan. Untuk pengujian efektivitas FMA G. margarita, juga digunakan rancangan perlakuan tunggal tidak terstruktur yang terdiri dari 5 perlakuan yaitu: Kontrol tanpa FMA $\left(\mathrm{e}_{0}\right)$, diberi FMA dengan waktu simpan 0 bulan $\left(\mathrm{e}_{1}\right), 6$ bulan $\left(\mathrm{e}_{2}\right), 12$ bulan $\left(\mathrm{e}_{3}\right)$, dan 22 bulan $\left(\mathrm{e}_{4}\right)$. Setiap perlakuan diulang sebanyak 5 kali dan setiap satuan percobaan diwakili oleh 2 tanaman jagung.

\section{Penyiapan media tanam, benih jagung, dan} aplikasi FMA. Media tanam yang digunakan untuk uji efektivitas sama dengan uji infeksi yaitu campuran pasir steril dan zeolite. Media dimasukkan sebanyak 8 $\mathrm{kg} /$ polibag. Cara penanaman benih jagung dan aplikasi mikoriza juga sama dengan penelitian daya infeksi. Polibag yang sudah ditanami disusun dan dipelihara di rumah kaca. Penyiraman dilakukan pada pagi dan sore hari dengan jumlah volume air yang sama untuk setiap perlakuan. Pupuk yang diberikan adalah pupuk Urea sebanyak $1 \mathrm{~g} /$ polibag pada 7,35 , dan 50 hari setelah tanam, sedangkan pupuk SP36 sebanyak 2 g/polibag dan $\mathrm{KCl}$ sebanyak 1,2 g/polybag diberikan pada 7 hari setelah tanam.

Pengambilan data. Pengamatan bobot segar dan bobot kering tajuk, bobot kering akar dan persen infeksi akaroleh FMA dilakukan 8 minggu setelah aplikasi G. margarita.

Analisis data. Data yang diperoleh dari kedua penelitian di atas dianalisis dengan uji Barlett dan dilanjutkan dengan uji sidik ragam dan uji BNT pada tarafalfa 5\%.

\section{HASIL DAN PEMBAHASAN}

\section{Uji daya infeksi FMA G. margarita.}

Pengamatan pada minggu ke 1 hingga ke 3 setelah aplikasi FMAmenunjukkan bahwa G. margarita yang digunakan pada penelitian ini telah mampu menginfeksi akar tanaman jagung pada 1 minggu setelah tanam untuk semua masa simpan (Tabel 1).

Pada Tabel 1 juga dapat dilihat bahwa pada waktu 2 minggu setelah aplikasi, masa simpan 6 bulan menghasilkan persen infeksi akar tertinggi diikuti oleh

Tabel 1. Persen infeksi FMA G. margarita yang telah disimpan 0, 6, dan 22 bulan pada akar tanaman jagung

\begin{tabular}{cccc}
\hline \multirow{2}{*}{ Waktu Simpan } & \multicolumn{3}{c}{ \% Infeksi Akar } \\
\cline { 2 - 4 } & $1 \mathrm{msa}$ & $2 \mathrm{msa}$ & $3 \mathrm{msa}$ \\
\hline 0 bulan & $4,0 \mathrm{a}$ & $23,0 \mathrm{a}$ & $90,5 \mathrm{~b}$ \\
6 bulan & $27,7 \mathrm{~b}$ & $70,7 \mathrm{~b}$ & $88,3 \mathrm{~b}$ \\
22 bulan & $11,7 \mathrm{a}$ & $57,7 \mathrm{~b}$ & $61,3 \mathrm{a}$ \\
\hline BNT 5\% & 10,2 & 19,5 & 17,4 \\
\hline
\end{tabular}

Keterangan: $\mathrm{msa}=$ minggu setelah aplikasi 
masa simpan 22 bulan, sedangkan masa simpan 0 bulan menghasilkan persen infeksi terendah. Namun, pada saat 3 minggu setelah aplikasi, persen infeksi FMA pada masa simpan 0 bulan ini menghasilkan persen infeksi tertinggi dengan hampir seluruh akar telah terkolonisasi (persen infeksi 90,5\%). Rendahnya infeksi akar pada masa simpan 0 bulan pada 1 dan 2 minggu setelah aplikasi dapat disebabkan oleh karena spora yang baru saja dipanen memiliki proses perkecambahan yang lambat sehingga proses infeksi pun berjalan lebih lambat. Hal ini dapat terjadi karena air yang masuk ke dalam spora untuk memicu proses perkecambahan lebih sedikit karena spora tersebut masih terisi oleh material cair di dalamnya. Hal yang sama dilaporkan oleh Daniels dan Graham (1976) pada spora FMA Glomus mosseae. Spora yang telah disimpan selama 8 bulan berkecambah lebih cepat dibandingkan dengan spora yang baru dipanen. Nilai persen infeksi lebih dari 50\% diperoleh pada minggu ke 2 untuk masa simpan 6 dan 22 bulan, dan pada minggu ke 3 untuk masa simpan 0 bulan. Pada Tabel 1 juga dapat dilihat bahwa semakin meningkatnya waktu semakin banyak akar yang diinfeksi oleh FMA. Hal ini mencerminkan bahwa jenis FMA G. margarita yang digunakan memiliki kecocokan dengan tanaman jagung sebagai inangnya.

Uji efektivitas $\boldsymbol{G}$ margarita. Hasil penelitian menunjukkan bahwa perlakuan masa simpan spora $G$. margarita mempengaruhi efektivitas fungi dalam meningkatkan pertumbuhan tanaman jagung. Data pada Tabel 2 memperlihatkan bahwa baik bobot segar maupun bobot kering tajuk tanaman jagung yang diberi FMA dengan masa simpan 0 bulan memiliki nilai yang lebih tinggi dari pada kontrol dan perlakuan masa simpan 6 bulan, namun tidak berbeda dengan perlakuan masa simpan 12 dan 22 bulan.

Data pada Tabel 3 menunjukkan bahwa bobot segar akar yang diberi perlakuan G. margarita dengan masa simpan 0,6, dan 12 bulan menghasilkan nilai yang lebih tinggi dari pada kontrol tanpa mikoriza. Begitu pula dengan persen infeksi FMA pada akar tanaman jagung. Pada 8 minggu setelah aplikasi, semua perlakuan FMA telah menghasilkan persen infeksi akar di atas 50\% dengan nilai infeksi tertinggi diperoleh dari perlakuan masa simpan 6 dan 12 bulan.

Berdasarkan data infeksi pada Tabel 3 dapat dilihat bahwa semua spora FMA yang telah disimpan hingga 22 bulan masih mampu menginfeksi akar tanaman jagung lebih dari $50 \%$ pada 8 minggu setelah

Tabel 2. Bobot basah dan bobot kering tanaman jagung 8 minggu setelah aplikasi G. margarita dengan masa simpan yang berbeda

\begin{tabular}{lcc}
\hline \multicolumn{1}{c}{ Waktu Simpan } & Bobot Basah Tajuk $(\mathrm{g})$ & Bobot Kering Tajuk $(\mathrm{g})$ \\
\hline Tanpa Mikoriza & $235,7 \mathrm{a}$ & $37,0 \mathrm{a}$ \\
0 bulan & $275,8 \mathrm{c}$ & $43,5 \mathrm{c}$ \\
6 bulan & $257,6 \mathrm{~b}$ & $40,5 \mathrm{~b}$ \\
12 bulan & $261,5 \mathrm{bc}$ & $41,8 \mathrm{bc}$ \\
22 bulan & $272,6 \mathrm{bc}$ & $42,8 \mathrm{bc}$ \\
\hline BNT 5\% & 15,2 & 2,8 \\
\hline
\end{tabular}


Tabel 3. Bobot basah dan infeksi akar tanaman jagung 8 minggu setelah aplikasi G. margarita dengan masa simpan yang berbeda

\begin{tabular}{lcc}
\hline \multicolumn{1}{c}{ Waktu Simpan } & Bobot Basah Akar $(\mathrm{g})$ & \% Infeksi Akar \\
\hline Tanpa Mikoriza & $62,4 \mathrm{a}$ & 15,4 \\
0 bulan & $73,5 \mathrm{~b}$ & 51,5 \\
6 bulan & $75,4 \mathrm{~b}$ & 98,0 \\
12 bulan & $73,6 \mathrm{~b}$ & 95,8 \\
22 bulan & $70,0 \mathrm{ab}$ & 62,8 \\
\hline BNT 5\% & 10,1 & \\
\hline
\end{tabular}

aplikasi, sehingga membentuk simbiosis antara FMA dengan tanaman jagung. Simbiosis ini memberikan pengaruh yang baik pada tanaman dengan meningkatnya pertumbuhan tanaman jagung (Tabel 2 dan Tabel 3). Syah et al. (2006) juga melaporkan bahwa spora yang disimpan hingga 18 bulan masih memiliki daya infeksi yang cukup baik.

Pada Tabel 3 juga dapat dilihat bahwa nilai persen infeksi spora yang disimpan selama 0 dan 22 bulan (51,5\% dan 62,8\%) lebih rendah daripada nilai infeksi spora dengan masa simpan 6 dan 12 bulan (98,0\% dan 95,8\%). Namun pertumbuhan tanaman tidak berbeda secara nyata. Persen infeksi akar menunjukkan telah terkolonisasinya akar oleh hifa FMA dan nilai infeksi tersebut mencerminkan struktur FMA di dalam akar tanaman. Data infeksi tidak dapat memberikan gambaran seberapa jauh hifa FMA berkembang di luar akar atau di dalam tanah. Banyak penelitian menyimpulkan bahwa, perkembangan hifa di dalam akar tidak berkorelasi positif dengan perkembangan hifa di luar akar. Oleh karena itu, persen infeksi yang lebih tinggi tidak selalu menghasilkan pertumbuhan tanaman yang juga lebih tinggi. Melati et al. (2011) juga melaporkan bahwa tingginya derajat infeksi tanaman inang tidak selalu menghasilkan pertumbuhan tanaman yang lebih baik. Peningkatan pertumbuhan tanaman inang lebih ditentukan oleh keaktifan FMA yang berkembang di luar akar tanaman dalam menyerap unsur hara dan air.

G. margarita yang digunakan dalam penelitian ini disimpan pada ruangan dengan suhu $20 \pm 2{ }^{\circ} \mathrm{C}$ dalam media pembawa campuran pasir dan zeolite dengan kadar air 0,3\%. Berdasarkan hasil uji infektivitas dan efektivitas yang dilakukan dapat diketahui bahwa spora G. margarita yang disimpan hingga 22 bulan masih mampu menginfeksi akar tanaman jagung dan selanjutnya meningkatkan pertumbuhan tanaman. Berdasarkan hasil penelitian ini dapat disarankan bahwa untuk menjaga viabilitas spora FMA sehingga tetap memiliki daya infeksi dan efektivitas yang tinggi, maka kondisi spora sebaiknya disimpan dalam media pembawa yang kering (untuk menghindari spora berkecambah) dan diletakkan dalam ruangan tidak terkena matahari langsung.

\section{KESIMPULAN}

Berdasarkan data hasil penelitian dapat diambil kesimpulan sebagai berikut: (1) Lama masa simpan 
spora mempengaruhi daya infeksi spora G. margarita terutama 1 dan 2 minggu setelah aplikasi; (2) spora G. margarita yang telah disimpan selama $0,6,12$, dan 22 bulan masih mampu menginfeksi akar tanaman jagung $>50 \%$ pada 8 minggu setelah aplikasi sehingga mampu meningkatkan pertumbuhan tanaman jagung melalui peningkatan bobot basah dan kering tajuk serta bobot basah akar.

\section{UCAPAN TERIMA KASIH}

Ucapan terima kasih diberikan kepada seluruh staf Laboratorium Produksi Perkebunan dan Mikoriza yang telah membantu dalam pelaksanaan penelitian ini.

\section{DAFTAR PUSTAKA}

Bharadwaj, D.P., Per-Olof, L., and Alstrom, S. 2008. Arbuscular mycorrhizal fungi spore-associated bacteria affect mycorrhizal colonization, plant growth, and potato pathogens. Soil Biology and Biochemistry 40 (10): 2494-2501.

Brundrett, M.N., Bougher, N., Del, B., Ove, T., and Malajczuk, N. 2008. Working with Mycorrhizas in Forestry and Agriculture. ACIAR Monograph 32. Australian Centerfor International Agriculture Research. Canberra. 374 p.

Daniels, B.A. and Graham, S.O. 1976. Effects of nutrition and soil extracts on germination of Glomus mosseae spores. Mycologya 68: 108-116.

Krisnarini, Rini, M.V., and Timotiwu, P.B. 2018. The growth of oil palm (Elaeis guineensis Jacq.) seedling with the application of different arbuscular mycorrhiza fungi and various phosphorus dosages. Journal of Tropical Soils 23 (3): 117-124.
Melati, M., Iskandar, M.P., Bambang, S.P., Hariyadi, dan Sri,W. 2011. Morfosiology dam hasil berbagai provenan jarak pagar (Jatropha curcas L.) dan asosiasinya dengan fungi mikoriza arbuskular di lapangan. Prosiding Seminar Nasional Mikoriza: Pupuk dan Pestisida Hayati Pendukung Pertanian Berkelanjutan yang Ramah Lingkungan. Universitas Lampung, halaman 99-113.

Rini, M.V., Susilowati, E., Riniarti, M., and Lukman, I. 2020. Application of Glomus sp. and a mix of Glomus sp. with Gigaspora sp. in improving the agarwood (Aquilaria malaccensis Lamk.) seedling growth inUltisol soil. IOP Conference series Earth and Environmental Science 449012004.

Rini, M.V., Jamal, T., Idris, Z. A. and Azizah, H. 2000. Effect of Arbuscular Mycorrhiza Fungi Colonization on Growth and Physiological Responses of Grafted Cocoa under Field Condition. Malaysian Journal of Soil Science, 4: $67-78$

Simanungkalit, R.D.M., Suriadikarta, D.A., Rasti, S., Diah, S., dan Wiwik, H. 2006. Pupuk Organik dan Pupuk Hayati. Balai Besar Litbang Sumberdaya Lahan Pertanian Bogor.

Smith, S.E. and Read, D.J. 2008. Mycorrhizal Symbiosis. Academic Press. New York. 614 p.

Strullu-Derrien, C., Marc-Andre, Selosse, Kenrick, P., and Martin, F.M. 2018. The origin and evolution of mycorrhizal symbiosis: from palaeomycology to phylogenomics. New Phytologist 220: 1012-1030.

Syah, A., Jumjunidang, M.J., dan Herizal, Y. 2006. Penyimpanan kapsul cendawan mikoriza arbuskular untuk mempertahankan daya multiplikasi dan infektivitas. Jurnal Hortikultura 16 (2): 129-133. 